\section{Comparative Effects of Evaporative Cooling, Kaolin Particle Film, and Shade Net on Sunburn and Fruit Quality in Apples}

\author{
Jiregna Gindaba ${ }^{1}$ and Stephanie J.E. Wand \\ Department of Horticultural Science, University of Stellenbosch, Private Bag \\ X1, Matieland 7602, Republic of South Africa
}

Additional index words. fruit color, fruit temperature, heat stress, Malus domestica, sunburn

\begin{abstract}
We investigated the effects of evaporative cooling (EC), kaolin particle film (KP) and $20 \%$ shade net (SN) on the control of sunburn, fruit temperature amelioration and fruit quality of 'Cripps' Pink' and 'Royal Gala' apples [Malus domestica Borkh.] under orchard conditions during the 2003-04 season in Stellenbosch, South Africa. On days with maximum air temperatures of 34 to $37^{\circ} \mathrm{C}$, SN fruit were 5.4 to $9.7^{\circ} \mathrm{C}$ cooler, EC fruit were 3.1 to 5.8 ${ }^{\circ} \mathrm{C}$ cooler and KP fruit were 1.5 to $6.4^{\circ} \mathrm{C}$ cooler compared to the control (nontreated, $\mathrm{CO}$ ) fruit. $\mathrm{SN}$ was effective in reducing fruit temperature from mid-morning until midafternoon; KP was most effective during late morning and early afternoon but not at midday; EC was effective from late morning on days when EC was activated. SN, followed by KP, was the most effective technique for controlling sunburn in fruit of both cultivars, with EC being less effective. The different technologies reduced fruit blush color compared to the $\mathrm{CO}$ treatment, with $\mathrm{SN}$ showing the most reduction and $\mathrm{EC}$ the least. EC increased fruit mass compared to all other treatments in 'Royal Gala', and also increased fruit diameter and mass compared to $\mathrm{CO}$ in 'Cripps' Pink'. We conclude that under the high radiation levels experienced in South African apple production areas, technologies which reduce irradiance as well as fruit temperature (KP, SN) are more effective in reducing sunburn than those which only reduce fruit temperature (EC). However, radiation-reducing technologies are potentially detrimental to color development on blushed apples.
\end{abstract}

Solar radiation is reported to cause sunburn (solar injury) in various crops (Lipton 1977; Parchomchuk and Meheriuk, 1996; Glenn et al., 2002; Schrader et al., 2003). High solar radiation during the summer results in excessive light and heat load on leaves and fruit. Although the relative contribution of heat and light stresses to sunburn is not yet clearly established, sunburn is caused by the interaction of high temperature and light (Glenn et al., 2002; Schrader et al., 2003). With the continued depletion of the stratospheric ozone layer, the levels of UV-B radiation (280 to 320 $\mathrm{nm}$ ) reaching the earth's surface are increasing (Kerr and McElroy, 1993). This, together with global warming associated with fossil fuel emission, indicates a possibility of increasing incidence of sunburn in the future.

Plants use several protective mechanisms to avoid sunburn, e.g., 1) dissipation of excess energy through the xanthophyll cycle (Demmig-Adams et al., 1995; Müller et al., 2001; Ma and Cheng, 2003), 2) induction of antioxidants (e.g., various phenolics, flavonols and proteins) to minimize oxidative damage (Mackerness and Thomas, 1999; Ma and Cheng, 2003;Merzlyak and Solovchenko, 2002; Solovchenko

Received for publication 14 Oct. 2004. Accepted for publication $11 \mathrm{Dec} .2004$. We are grateful to the South African Deciduous Fruit Producers' Trust and the University of Stellenbosch for financial support, Mr. M. du Toit for managing the orchard and EC system, and Dr. W.J. Steyn for his contribution to establishing the EC system.

${ }^{1}$ Corresponding author; e-mail jgindaba@sun.ac.za. involves an over-tree irrigation system to cool down the fruit when air temperature exceeds a certain threshold. It reduces fruit temperature and sunburn, improves red fruit color in some cultivars and increases soluble solid content (Parchomchuk and Meheriuk, 1996; Unrath, 1972; Unrath and Sneed, 1974). In South Africa, trials carried out on two cultivars of apple (Kotzé et al., 1988) indicate that EC suppressed the incidence of sunburn.

$\mathrm{KP}$ is a technology that involves the use of kaolin particles that are reflective to radiation, especially UV wavelengths reaching the surfaces of leaves and fruit, thereby lowering leaf and fruit surface temperatures (Glenn et al., 2002). The positive effects of kaolin for controlling sunburn in various fruit have recently been well documented (e.g., Glenn et al., 2002; Le Grange et al., 2004; Melgarejo et al., 2004; Schupp et al., 2002; Wünsche et al., 2004).

SN involves the attenuation of solar irradiance by shading, thereby reducing temperature and wind velocity and increasing humidity. The application of $\mathrm{SN}$ in orchards originated from the ameliorative effect of shade on radiation and temperature observed under natural conditions. Several studies (e.g., Funke et al., 2003; Guerrero et al., 2002; Stampar et al., 2001; Widmer, 2001) reported the dual use of hail nets for protection from hail storms and sunburn. However, attenuation of solar irradiance may affect color development in red apple cultivars (Funke et al., 2003; Guerrero et al., 2002; Widmer, 2001). Studies on the effects of hail net on apple fruit yield and quality show controversial results. Chen et al. (1998) reported negative impact of hail net on fruit yield and quality; Stampar et al. (2001) reported no effect of hail net on yield but significantly improved fruit quality while Widmer (2001) and Funke et al. (2003) reported no definite influence of hail net on maturity and quality of apple fruits.

Although EC systems have been used commercially for a number of years in South Africa (Wand et al., 2002), KP and SN are relatively new technologies that are drawing the attention of fruit growers. Yet no comparative studies under the same orchard conditions have been made available to growers for selection of an appropriate method to mitigate sunburn. The objective of the current study was, therefore, to investigate and compare the effectiveness of $\mathrm{EC}, \mathrm{KP}$, and SN on fruit temperature amelioration, control of sunburn and effects on fruit quality under the same orchard conditions in South Africa.

\section{Materials and Methods}

Study site. A 5-year-old mixed orchard composed of two cultivars of apple (Malus domestica Borkh.), 'Cripps' Pink' and 'Royal Gala' at Welgevallen Experimental Farm, Stellenbosch, South Africa $\left(33^{\circ} 55^{\prime} \mathrm{S} ; 1^{\circ} 8^{\circ} \mathrm{E}\right)$ was used during the 2003/2004 season. The trees were grafted on M793 rootstock and planted with a NE to SW row orientation at spacing of $3.8 \times 1.25 \mathrm{~m}$. They were trained as a central leader on a three wire training system. The 
trees were irrigated with microjet sprinklers scheduled using neutron moisture probe measurements. No adjustments were made under the EC treatments.

Experimental design and treatments. A completely randomized block design with six blocks of 'Cripps' Pink' and six blocks of 'Royal Gala' was used. Each block consisted of 20 trees of which two were cross-pollinators and not used. One tree per block per cultivar was assigned to each of the four treatments: evaporative cooling (EC), kaolin-based particle film (KP), shade net (SN) and control (CO). Two to three trees were left as buffers between the treatments to avoid water from the overhead sprinklers of the EC system, or the KP sprays from reaching the other trees. The EC system was installed in 2001-02 on 4.5-m poles spaced $8 \mathrm{~m}$ from each other. Sprinkler jets (DAN 2001, Tel Aviv, Israel) were placed every 2.5

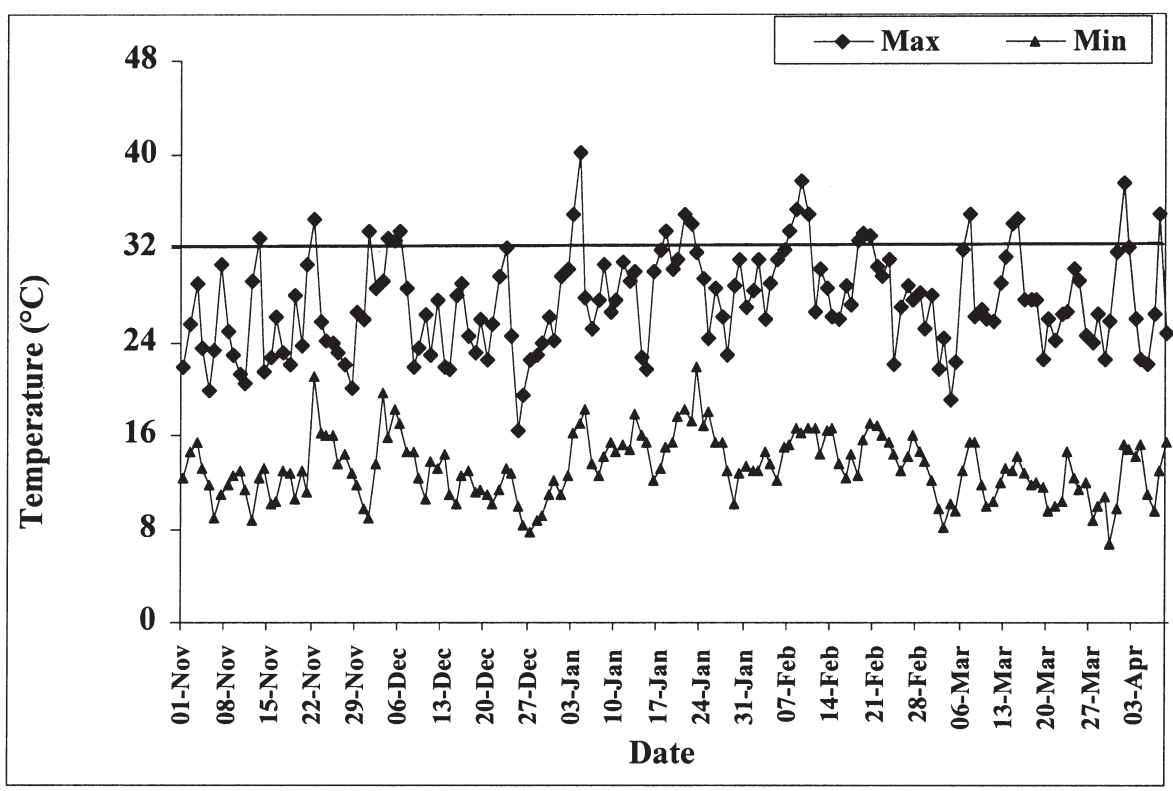

Fig. 1. Daily maximum and minimum air temperatures recorded by a weather station close to the experimental orchard during the 2003-04 season. The horizontal line indicates the threshold air temperature for sunburn incidence.

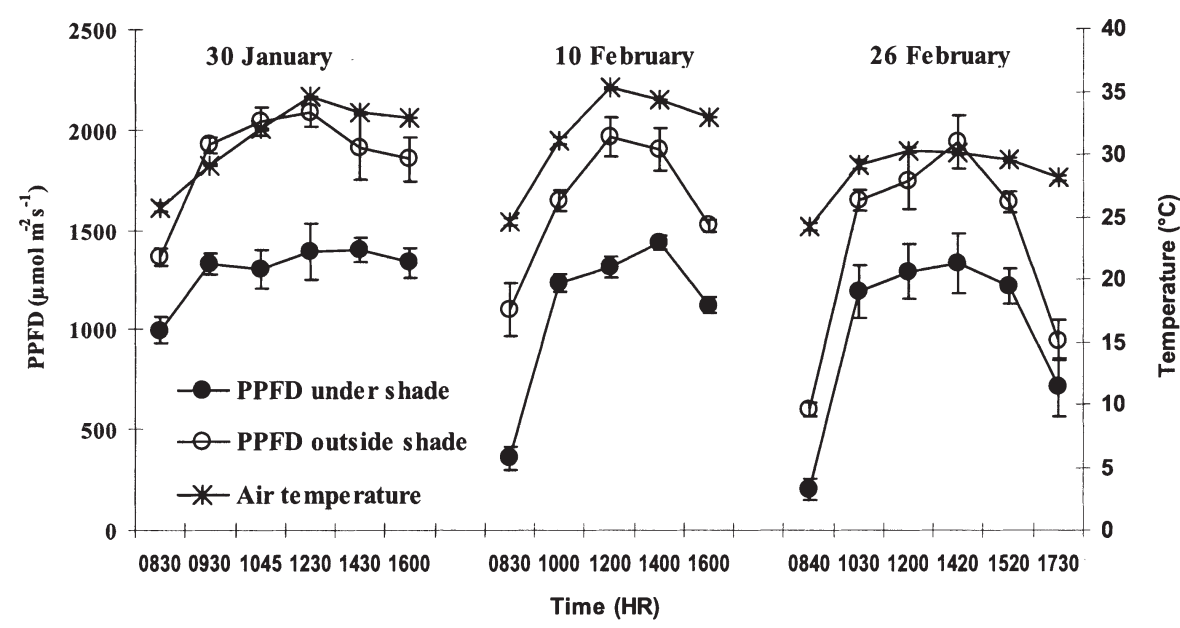

Fig. 2. Diurnal courses of photosynthetic photon flux density (PPFD) under shade net and outside shade net, on three days during which diurnal fruit skin temperature was measured. Error bars represent standard errors. $m$ along the main pipe to discharge water over the trees at a height of $3.5 \mathrm{~m}$. Each jet covered a radius of about $1.5 \mathrm{~m}$ with a discharge rate of $28 \mathrm{~L} \cdot \mathrm{h}^{-1}\left(4.5 \mathrm{~mm} \cdot \mathrm{h}^{-1}\right)$. The EC system was computer-controlled and linked to a shielded temperature sensor installed in the orchard. The EC system was activated for $5 \mathrm{~min}$ and closed for $15 \mathrm{~min}$ at air temperatures of $30{ }^{\circ} \mathrm{C}$ during the day (between 0600 and $1800 \mathrm{HR}$ ) and at and $2100 \mathrm{HR}$ ). This scheduling is the result of fine-tuning the system over three previous surface (Schrader et al., 2003), without the detrimental effects on fruit quality resulting from overly wet soils (S.J.E. Wand, unpublished data). We found that canopies and fruit on our relatively open trees were fully wet after $5 \mathrm{~min}$ EC irrigation, and fruit surface temperatures rose $22{ }^{\circ} \mathrm{C}$ during the early evening (between 1800 by a maximum of 6 to $7^{\circ} \mathrm{C}$ between pulses (S.J.E. Wand, unpublished data), maintaining temperatures under the critical threshold.

The EC treatment was started on 10 Dec. 2003, 12 weeks after full bloom. Black shade net (SN) manufactured to intercept $20 \%$ solar radiation was installed around individual trees on 8 Dec. 2003. As much as possible the SN was prevented from touching the branches by stretching it on the wires and poles used for training the trees. Six percent kaolin-based particle film (Surround WP, Engelhard Corporation, Iselin, N.J.) was first applied on 10 Dec. 2003 and repeated on 16 Jan. 2004 at a concentration of $3 \%$. A surfactant (Agral) was used at a rate of $20 \mathrm{~mL} / 100 \mathrm{~L}$ water. The whole tree was sprayed from both sides and top for uniform coverage using a hand-held spray apparatus. The volume of spray was $3 \pm 0.5$ $\mathrm{L} /$ tree depending on the tree canopy size. Due to excellent maintenance of coverage it was not necessary to make further applications. No treatments were applied to the control trees.

Measurements of PPFD, air and fruit temperature. Seasonal air temperature was monitored using two thermistors attached to an automatic data logger positioned in the orchard (CR10X; Campbell Scientific Inc, Logan, Utah). Seasonal minimum and maximum temperatures are shown in Fig. 1.

The diurnal courses of photosynthetic photon flux density (PPFD), air temperature and fruit surface temperature were monitored on 30 Jan., 10 and 26 Feb. 2004. PPFD under and outside the SN was monitored using a LI-189 quantum sensor attached to a LI-6400 photosynthesis system (LI-COR, Lincoln, Neb.). Air temperature was measured using a digital thermo-hygrometer (SAM990DW). Figure 2 shows the diurnal courses of PPFD inside and outside $\mathrm{SN}$ and air temperature on the three measurement days.

The diurnal courses of fruit surface temperature were monitored using an infrared thermometer (Raynger MX 4; Raytek Corp.). Surface temperature measurements were taken on five sun-exposed fruit per tree per treatment at regular intervals during the day. The infrared thermometer was held at a distance of about $0.3 \mathrm{~m}$ from the fruit and at an angle of about $150^{\circ}$ with respect to the fruit and the sun. Because the emissivity of KP is equivalent to that of plant material (Glenn et al., 2002), emissivity was adjusted to 0.95 for both the KP sprayed and unsprayed fruit. Although measurements were made on the same fruit during the day, measurement spots on the fruit surface changed gradually with the changing angle of the sun.

Sunburn. Sunburn was scored on 29 Jan. 2004 and at harvest for each cultivar, using all fruit on the tree, according to a visual detection of exposed fruit surfaces. Fruit with yellowish-brown skin to those with clear necrosis were scored as having sunburn. The amount of sunburn on a tree was expressed as a percentage of the total number of fruit on the tree.

Fruit quality assessment. 'Royal Gala' fruit were harvested on 11 Feb. 2004 while 'Cripps' Pink' fruit were harvested on 20 Apr. 2004. Forty sample fruit were collected from 
Table 1. Diurnal course of sun-exposed fruit surface temperatures as affected by evaporative cooling (EC), kaolin particle film (KP), shade net (SN), or control (CO) in two apple cultivars. Measurements were taken on 30 Jan. and 10 and 26 Feb. for 'Cripps' Pink' and on 30 Jan. and 10 Feb. for 'Royal Gala'. Mean values in a row followed by different letters are significantly different (LSD test at $P \leq 0.05$ ). Values are mean $\pm \operatorname{SE}(n=6)$

\begin{tabular}{lcccc}
\hline Time (HR) & EC & KP & SN & CO \\
\hline 'Cripps' Pink' 30 Jan. & $24.4 \pm 0.31 \mathrm{a}$ & $25.0 \pm 0.20 \mathrm{a}$ & $24.7 \pm 0.25 \mathrm{a}$ & $24.8 \pm 0.21 \mathrm{a}$ \\
0830 & $36.5 \pm 0.41 \mathrm{a}$ & $34.8 \pm 0.55 \mathrm{ab}$ & $32.8 \pm 0.42 \mathrm{c}$ & $34.4 \pm 0.26 \mathrm{bc}$ \\
0930 & $39.1 \pm 0.45 \mathrm{ab}$ & $37.4 \pm 0.56 \mathrm{~b}$ & $37.3 \pm 0.63 \mathrm{~b}$ & $40.6 \pm 0.76 \mathrm{a}$ \\
1045 & $36.1 \pm 0.60 \mathrm{~b}$ & $40.7 \pm 0.56 \mathrm{a}$ & $35.4 \pm 0.94 \mathrm{~b}$ & $41.0 \pm 0.48 \mathrm{a}$ \\
1230 & $34.3 \pm 0.77 \mathrm{bc}$ & $36.3 \pm 0.49 \mathrm{~b}$ & $32.6 \pm 0.23 \mathrm{c}$ & $40.0 \pm 0.61 \mathrm{a}$ \\
1430 & $35.0 \pm 0.54 \mathrm{~b}$ & $37.0 \pm 0.43 \mathrm{ab}$ & $35.7 \pm 0.81 \mathrm{~b}$ & $38.8 \pm 0.39 \mathrm{a}$ \\
1600 & & & & \\
'Royal Gala' 30 Jan. & $25.9 \pm 0.31 \mathrm{a}$ & $26.5 \pm 0.20 \mathrm{a}$ & $26.2 \pm 0.25 \mathrm{a}$ & $26.3 \pm 0.21 \mathrm{a}$ \\
0830 & $36.4 \pm 0.42 \mathrm{a}$ & $33.8 \pm 0.65 \mathrm{~b}$ & $33.0 \pm 0.31 \mathrm{~b}$ & $35.6 \pm 0.27 \mathrm{a}$ \\
0930 & $41.2 \pm 0.77 \mathrm{ab}$ & $40.1 \pm 0.89 \mathrm{~b}$ & $37.2 \pm 0.77 \mathrm{c}$ & $43.4 \pm 0.59 \mathrm{a}$ \\
1045 & $38.8 \pm 1.14 \mathrm{ab}$ & $40.1 \pm 1.27 \mathrm{a}$ & $35.1 \pm 1.24 \mathrm{~b}$ & $41.3 \pm 0.92 \mathrm{a}$ \\
1230 & $39.7 \pm 0.64 \mathrm{~b}$ & $38.5 \pm 0.56 \mathrm{~b}$ & $35.7 \pm 0.37 \mathrm{c}$ & $43.2 \pm 1.10 \mathrm{a}$ \\
1430 & $38.1 \pm 1.14 \mathrm{ab}$ & $37.9 \pm 0.83 \mathrm{ab}$ & $34.8 \pm 0.47 \mathrm{~b}$ & $40.9 \pm 1.23 \mathrm{a}$ \\
1600 & & & & \\
'Cripps' Pink' 10 Feb. & $25.4 \pm 0.31 \mathrm{a}$ & $26.0 \pm 0.20 \mathrm{a}$ & $25.7 \pm 0.25 \mathrm{a}$ & $25.8 \pm 0.21 \mathrm{a}$ \\
0830 & $37.5 \pm 0.35 \mathrm{a}$ & $37.5 \pm 0.58 \mathrm{a}$ & $35.3 \pm 0.55 \mathrm{~b}$ & $39.1 \pm 0.34 \mathrm{a}$ \\
1000 & $40.3 \pm 0.76 \mathrm{a}$ & $42.5 \pm 1.04 \mathrm{a}$ & $34.4 \pm 1.05 \mathrm{~b}$ & $41.2 \pm 0.27 \mathrm{a}$ \\
1200 & $33.6 \pm 1.15 \mathrm{c}$ & $37.0 \pm 0.74 \mathrm{~b}$ & $36.8 \pm 0.21 \mathrm{~b}$ & $40.7 \pm 0.38 \mathrm{a}$ \\
1400 & $35.0 \pm 0.54 \mathrm{~b}$ & $36.9 \pm 0.42 \mathrm{ab}$ & $35.8 \pm 0.82 \mathrm{~b}$ & $38.9 \pm 0.40 \mathrm{a}$ \\
1600 & & & & \\
'Royal Gala' 10 Feb. & $26.9 \pm 0.31 \mathrm{a}$ & $27.5 \pm 0.20 \mathrm{a}$ & $27.2 \pm 0.25 \mathrm{a}$ & $27.3 \pm 0.21 \mathrm{a}$ \\
0830 & $41.4 \pm 0.58 \mathrm{a}$ & $39.0 \pm 0.53 \mathrm{~b}$ & $36.1 \pm 0.34 \mathrm{c}$ & $42.3 \pm 0.53 \mathrm{a}$ \\
1000 & $44.5 \pm 0.60 \mathrm{a}$ & $39.0 \pm 1.72 \mathrm{~b}$ & $38.8 \pm 1.70 \mathrm{~b}$ & $46.8 \pm 0.43 \mathrm{a}$ \\
1200 & $37.9 \pm 0.53 \mathrm{c}$ & $42.3 \pm 0.94 \mathrm{~b}$ & $35.2 \pm 0.55 \mathrm{~d}$ & $47.3 \pm 0.91 \mathrm{a}$ \\
1400 & $37.4 \pm 1.39 \mathrm{ab}$ & $37.6 \pm 0.72 \mathrm{ab}$ & $35.2 \pm 0.57 \mathrm{~b}$ & $40.8 \pm 1.23 \mathrm{a}$ \\
1600 & & & & \\
'Cripps' Pink' 26 Feb. & $25.4 \pm 0.31 \mathrm{a}$ & $26.0 \pm 0.20 \mathrm{a}$ & $25.7 \pm 0.25 \mathrm{a}$ & $25.8 \pm 0.21 \mathrm{a}$ \\
0840 & $35.5 \pm 0.69 \mathrm{a}$ & $32.3 \pm 2.08 \mathrm{~b}$ & $32.4 \pm 0.85 \mathrm{~b}$ & $36.7 \pm 0.76 \mathrm{a}$ \\
1030 & $40.4 \pm 0.30 \mathrm{a}$ & $38.2 \pm 0.77 \mathrm{a}$ & $32.4 \pm 1.52 \mathrm{~b}$ & $39.4 \pm 0.37 \mathrm{a}$ \\
1200 & $38.4 \pm 0.74 \mathrm{a}$ & $36.4 \pm 0.48 \mathrm{~b}$ & $31.9 \pm 0.52 \mathrm{c}$ & $38.6 \pm 0.79 \mathrm{a}$ \\
1420 & $31.8 \pm 1.01 \mathrm{a}$ & $29.0 \pm 0.40 \mathrm{a}$ & $29.2 \pm 0.23 \mathrm{a}$ & $30.8 \pm 1.80 \mathrm{a}$ \\
1520 & $28.3 \pm 0.48 \mathrm{ab}$ & $30.5 \pm 0.12 \mathrm{a}$ & $26.7 \pm 0.37 \mathrm{~b}$ & $29.4 \pm 0.32 \mathrm{a}$ \\
1730 & & & &
\end{tabular}

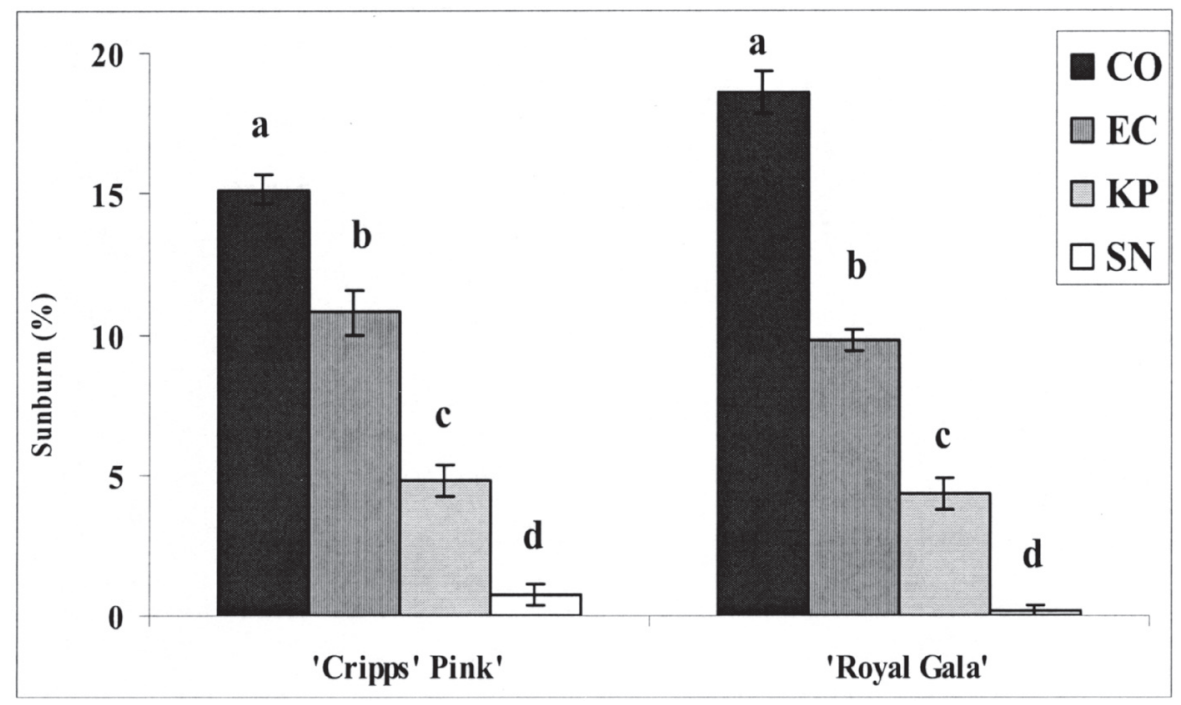

Fig. 3. Percentage sunburn of 'Cripps' Pink' and 'Royal Gala' apple fruit grown with evaporative cooling (EC), kaolin particle film (KP), shade netting (SN) or control (CO) during the 2003-04 season. Error bars represent standard errors. Mean values for each cultivar followed by different letters are significantly different (LSD test at $P \leq 0.05$ ).

each tree and assessments were made in a laboratory at the Department of Horticultural Science, Stellenbosch University. Fruit mass, equatorial diameter and color were measured on all samples. A colorimeter (NR-3000; Nippon Denshoku, Tokyo, Japan) was used to measure the hue angle of the sun-exposed and shaded surfaces. Fruit firmness and per- determined for five replicates per treatment using a digital hand-held pocket refractometer (PAL-1, UNI-IT Inc., Tokyo, Japan).

Statistical analyses. Data for fruit surface temperature and fruit quality parameters were subjected to one-way ANOVA based on the experimental design. ANCOVA was conducted for fruit diameter and mass using number of fruit per tree as covariate. Treatment means were separated using Fisher's protected least significant difference (LSD). All statistical computations were made using SAS (version 6.12), and significance was set at the $5 \%$ level.

\section{Results}

Fruit surface temperature. Fruit under EC treatment had comparable surface temperature to the control fruit over the whole day on 26 Feb. (Table 1). The maximum mean air temperature on that day was $30.6^{\circ} \mathrm{C}$ and the EC ran for only $5 \mathrm{~min}$. On the other days, the EC fruit showed significant differences in surface temperature compared to $\mathrm{CO}$ fruit only after the onset of overhead irrigation during the late morning and afternoon. Generally, SN markedly reduced fruit surface temperature from midmorning until midafternoon, and to a larger degree than EC or KP. KP significantly reduced fruit surface temperature during the late morning and early afternoon, but generally not during midday.

Sunburn. The average incidence of sunburn, as computed from the two recording dates, was $15.2 \%$ for 'Cripps' Pink' and $18.6 \%$ for 'Royal Gala' (Fig. 3). All three technologies used to reduce sunburn showed significant positive effects compared to the $\mathrm{CO}$ treatment in both 'Cripps' Pink' and 'Royal Gala' apples (Fig. 3 ). However, the effectiveness of the three technologies differed, with SN being most effective followed by KP.

Fruit color. The hue angles of sun-exposed and shaded fruit surfaces are given in Table 2. Higher hue angle indicates less blush or greener color. Generally, the ranking of the treatments in descending order of sun-exposed surface blush color (hue angle) was $\mathrm{CO}>\mathrm{EC}$ $>\mathrm{KP}>\mathrm{SN}$ in both cultivars. In 'Cripps' Pink' $\mathrm{KP}$ and $\mathrm{SN}$ had significantly reduced blush color compared to $\mathrm{CO}$, although the absolute difference between KP and CO was small. In 'Royal Gala' all treatments gave significantly lower blush color than $\mathrm{CO}$, but the EC effect was small. Significant variations in hue angle were also observed for shaded fruit surfaces, being significantly greener (or less blushed) in SN compared to EC, KP and CO fruit in both cultivars (Table 2). EC and KP resulted in less green (or more blushed) skin compared to CO in 'Cripps' Pink', but in 'Royal Gala' EC resulted in greener skin compared to CO.

Fruitfirmness. The sun-exposed and shaded side flesh firmness of fruit grown under the different sunburn control measures are given in Table 2. In 'Cripps' Pink', SN reduced firmness compared to $\mathrm{CO}$ and $\mathrm{KP}$ in the sunexposed side. In 'Royal Gala', EC generally increased fruit firmness in both sun-exposed and shaded sides compared to all other treat- 
Table 2. Color, firmness, starch conversion and total soluble solids, diameter and fresh mass of 'Cripps' Pink' and 'Royal Gala' fruit grown with evaporative cooling, kaolin particle film, shade net or control. Significant $P$ values are according to a one-way ANOVA at $95 \%$ confidence interval. Mean values in a row followed by different letters are significantly different (LSD test at $P \leq 0.05)$. Values are mean $\pm \mathrm{SE}(\mathrm{n}=6)$

\begin{tabular}{|c|c|c|c|c|c|}
\hline $\begin{array}{l}\text { Fruit quality } \\
\text { attributes }\end{array}$ & Cultivar & $\mathrm{EC}$ & $\mathrm{KP}$ & $\mathrm{SN}$ & $\mathrm{CO}$ \\
\hline \multirow[t]{2}{*}{ Sun-exposed surface color (hue) } & 'Cripps’ Pink' & $28.3 \pm 0.61 b c$ & $29.8 \pm 0.97 b$ & $36.8 \pm 1.16 \mathrm{a}$ & $27.2 \pm 0.59 \mathrm{c}$ \\
\hline & 'Royal Gala' & $36.7 \pm 0.89 \mathrm{c}$ & $41.1 \pm 2.15 b$ & $45.2 \pm 1.12 \mathrm{a}$ & $32.2 \pm 0.53 \mathrm{~d}$ \\
\hline \multirow[t]{2}{*}{ Shaded surface color (hue) } & 'Cripps' Pink' & $95.7 \pm 1.00 \mathrm{c}$ & $94.9 \pm 1.23 \mathrm{c}$ & $104.2 \pm 0.70 \mathrm{a}$ & $98.4 \pm 0.87 b$ \\
\hline & 'Royal Gala' & $90.9 \pm 0.99 b$ & $88.2 \pm 1.26 b c$ & $96.8 \pm 0.96 \mathrm{a}$ & $86.5 \pm 1.13 c$ \\
\hline \multirow[t]{2}{*}{ Sun-exposed side firmness (kg) } & 'Cripps' Pink' & $8.10 \pm 0.08 b c$ & $8.42 \pm 0.08 \mathrm{a}$ & $8.01 \pm 0.08 \mathrm{c}$ & $8.29 \pm 0.08 \mathrm{ab}$ \\
\hline & 'Royal Gala' & $9.05 \pm 0.11 \mathrm{a}$ & $8.69 \pm 0.11 b$ & $8.77 \pm 0.11 \mathrm{ab}$ & $8.51 \pm 0.09 b$ \\
\hline \multirow[t]{2}{*}{ Shaded side firmness (kg) } & 'Cripps' Pink' & $7.99 \pm 0.08 \mathrm{a}$ & $8.26 \pm 0.08 \mathrm{a}$ & $8.05 \pm 0.08 \mathrm{a}$ & $8.20 \pm 0.08 \mathrm{a}$ \\
\hline & 'Royal Gala' & $8.83 \pm 0.09 a$ & $8.64 \pm 0.10 \mathrm{ab}$ & $8.56 \pm 0.09 b$ & $8.30 \pm 0.09 b$ \\
\hline \multirow[t]{2}{*}{ Starch conversion $(\%)$} & 'Cripps' Pink' & $47.2 \pm 2.15 \mathrm{a}$ & $48.3 \pm 2.04 \mathrm{a}$ & $45.1 \pm 2.08 \mathrm{a}$ & $50.3 \pm 2.07 \mathrm{a}$ \\
\hline & 'Royal Gala' & $52.1 \pm 3.29 \mathrm{a}$ & $45.2 \pm 2.94 \mathrm{a}$ & $41.4 \pm 3.09 \mathrm{a}$ & $49.0 \pm 2.72 \mathrm{a}$ \\
\hline \multirow[t]{2}{*}{ Total soluble solids (\%) } & 'Cripps' Pink' & $14.7 \pm 0.14 b$ & $15.4 \pm 0.21 \mathrm{a}$ & $14.7 \pm 0.22 b$ & $15.4 \pm 0.24 \mathrm{a}$ \\
\hline & 'Royal Gala' & $13.3 \pm 0.21 \mathrm{a}$ & $13.4 \pm 0.24 \mathrm{a}$ & $12.9 \pm 0.30 \mathrm{a}$ & $13.9 \pm 0.19 \mathrm{a}$ \\
\hline \multirow[t]{2}{*}{ Diameter (mm) } & 'Cripps' Pink' & $63.9 \pm 0.40 \mathrm{a}$ & $63.7 \pm 0.32 \mathrm{ab}$ & $63.0 \pm 0.33 \mathrm{ab}$ & $62.3 \pm 0.37 b$ \\
\hline & 'Royal Gala' & $65.2 \pm 0.31 \mathrm{a}$ & $62.4 \pm 0.36 b$ & $63.2 \pm 0.33 \mathrm{ab}$ & $63.7 \pm 0.39 \mathrm{ab}$ \\
\hline \multirow[t]{2}{*}{$\operatorname{Mass}(\mathrm{g})$} & 'Cripps' Pink' & $114.0 \pm 1.84 \mathrm{a}$ & $114.6 \pm 1.61 \mathrm{a}$ & $109.1 \pm 1.51 \mathrm{ab}$ & $107.9 \pm 1.67 b$ \\
\hline & 'Royal Gala' & $123.8 \pm 1.58 \mathrm{a}$ & $114.9 \pm 1.83 b$ & $114.4 \pm 1.61 b$ & $117.5 \pm 2.04 b$ \\
\hline
\end{tabular}

ments. Maximum differences were, however, only about $0.5 \mathrm{~kg}$.

Starch conversion and TSS. The starch conversion and TSS of fruit grown under the different sunburn control measures are given in Table 2. All three technologies did not result in any significant effect on starch conversion in both cultivars (Table 2). EC and SN significantly reduced TSS in 'Cripps' Pink' compared to CO and KP, but there were no effects on TSS in 'Royal Gala'.

Fruit diameter and mass. The diameter and fresh mass of fruit grown under the different sunburn control measures are given in Table 2. EC significantly increased fruit fresh mass compared to the other treatments in 'Royal Gala', and diameter was increased relative to KP. In 'Cripps' Pink', both EC and KP resulted in significantly higher fruit mass compared to $\mathrm{CO}$, but diameter increases were significant only under EC.

\section{Discussion}

The observed temperature difference of 10 to $12{ }^{\circ} \mathrm{C}$ between the sun-exposed fruit skin and air temperature at noon and early afternoon clearly show that apple fruit have a high affinity to absorb solar radiation. However, fruit are unable to utilize or dissipate the excess radiation (Blanke and Lenz, 1989; Jones, 1981) which when accumulated would result in rising fruit surface temperature and ultimately localized burning of the fruit skin under hot climates. Although 'Cripps' Pink' and 'Royal Gala' are regarded as less susceptible to sunburn compared to other apple cultivars such as 'Braeburn' and 'Granny Smith' (Palmer et al., 2003), the observed $15 \%$ to $19 \%$ sunburn during the 2003-04 season was substantial. Maximum daily air temperatures exceeded 35 ${ }^{\circ} \mathrm{C}$ on 4 Jan., 8 to 10 Feb. and 1 Apr. 2003-04 (Fig. 1) which could result in a threshold fruit surface temperature of over $45^{\circ} \mathrm{C}$ at which sunburn may occur (Schrader et al., 2003). The major cause of the sunburn might be the heat wave on 4 Jan. 2004 when maximum daily air temperature reached $40{ }^{\circ} \mathrm{C}$ (Fig. 1).

The ameliorative effect of EC on fruit temperature observed in the current study agrees with former reports (e.g., Parchomchuk and Meheriuk, 1996; Unrath, 1972; Unrath and Sneed, 1974). However, when radiation is so intense, temperature reductions are not enough that radiation can burn fruit even when evaporating water droplets are on fruit surface. Unlike EC which only reduces fruit temperature via evaporation of water, $\mathrm{SN}$ and $\mathrm{KP}$ reflect some solar irradiance (including UV-B) in addition to reducing fruit surface temperature (Funk et al., 2003; Glenn et al., 2002; Wünsche et al., 2004). Due to these distinctive effects, sunburn was almost eliminated under the SN treatment and greatly reduced under KP treatment. Study by Le Grange et al. (2004) reported significant reduction in sunburn incidence by KP in 'Royal Gala' and 'Fuji' during the 1998-99 growing season in South Africa. In the present study, KP effectively reduced sunburn in both cultivars compared to $\mathrm{CO}$ and EC (Fig. 3) though it was less effective in ameliorating fruit surface temperature compared to EC. The advantage with KP lies in its ability to reflect the shorter wavelengths which are so injurious to fruit skin. Studies by Glenn etal. (2002) demonstrated that $\mathrm{KP}$ is reflective to UV wavelengths reaching the surfaces of leaves and fruit in addition to lowering their surface temperatures.

Although SN was the most effective technique in reducing fruit skin temperature and ultimately sunburn, fruit developed under the $\mathrm{SN}$ had very poor blush color development. In agreement with the current study, Stampar et al. (2001); Guerrero et al. (2002) and Funke et al. (2003) reported that hail nets, especially black nets, have reducing effects on fruit color development in apples. KP, ranking second to $\mathrm{SN}$ in controlling sunburn in both cultivars, also reduced the red color of the sun-exposed fruit surface in both cultivars, though not as severely as under SN. Such a negative impact of KP on red color development was also observed in 'Fuji' and 'Honeycrisp' (Schupp et al., 2002). However, Glenn et al. (2001) and Wünsche et al. (2004) observed comparable or higher color development under KP compared to untreated fruit but with deep red cultivars. Our results disagree with former reports (Iglesias et al., 2000; Iglesias et al., 2002; Unrath, 1972; Unrath and Sneed, 1974) regarding the improvement of color with EC. Similar to Parchomchuk and Meheriuk (1996) we did not observe significant color differences between $\mathrm{EC}$ and control fruit.

The three technologies did not show distinct effects on fruit maturity as indicated by TSS, starch conversion and firmness in both cultivars. The current study agrees with Schupp et al. (2002) who observed no significant effect of KP on TSS and starch degradation patterns in 'Fuji', and with Glenn et al. (2001) who observed no significant difference in TSS and firmness between KP treated and untreated fruit of various apple cultivars. Effects of EC and $\mathrm{SN}$ on fruit maturity were not consistent in both cultivars. EC improved fruit firmness only in 'Royal Gala', which was in agreement with studies on 'Topred Delicious' in Spain (Iglesias et al., 2002).

In agreement with a former report (Iglesias et al., 2002; Wand et al., 2002), EC increased fruit size in both cultivars (Table 2 ) indicating its ameliorative effect on leaves with possible enhancement of photosynthetic rate. Wand et al. (2002) suggested that in response to additional soil moisture and milder atmosphere (lower temperature and higher humidity) under $\mathrm{EC}$, trees respond by keeping their stomata open for increased photosynthesis. Milder atmosphere also minimizes respiratory losses from leaves and fruit, making more carbohydrate available for fruit growth. Although SN may also have comparable effects as EC on the atmosphere around the plant, 'Royal Gala' fruit developed under $\mathrm{SN}$ were smaller in size compared to those under EC due to the effect of shading on photosynthesis (J. Gindaba, unpublished data). Shading reduces stomatal density, amounts of Calvin-cycle enzymes per unit leaf area, number of chloroplasts per cell, volume of stroma per chloroplast, and stroma-exposed thylakoid membranes, all of which reduce the photosynthetic capacity of the leaf (Lambers et al., 1998). Furthermore, shading may directly reduce the photosynthetic rate of leaves when solar radiation is optimum, as on cloudy days.

Though SN is the most effective technology in reducing fruit skin temperature and sunburn in apple fruit, its negative impact on blush color 
development makes it less useful in commercial farms. Funke et al. (2003) suggested the use of reflective ground cover in the tree alleys under black or white hail nets to effectively enhance fruit coloration. However, this will make the use of SN expensive. Alternatively, nets of lower density (e.g., $<15 \%$ ) may be used to minimize the impact of SN on fruit quality.

Given its lower effectiveness in controlling sunburn, high cost of installation and higher water requirement, an EC system must also be subjected to regular check-ups and monitoring of the quality of irrigation water. Failure of the EC system just for one day may result in a substantial loss depending on the temperature maxima. KPand $\mathrm{SN}$ require much less attention compared to EC. However, KP application is less costly compared to the installation of SN structures.

Therefore, if satisfactory fruit quality could not be achieved using SN of lower density, KP could be a good alternative to SN. KP application is easier, cheaper and requires less attention. Removal of the KP deposit at harvest may require additional system for brushing/washing off the residue (Le Grange et al., 2004; Schupp et al., 2002). Such a system has recently been developed for South African apple pack houses, which appears to remove the residue successfully, but this system is still being tested by the industry. According to Wünsche et al. (2004), a conventional postharvest water bath to remove insects, dust, and other adhering materials can effectively remove KP residues on the fruit surface.

\section{Literature cited}

Bergh, O., J. Franken, E.J. Van Zyl, F. Kloppers, and A. Dempers. 1980. Sunburn on apples: Preliminary results of an investigation conducted during the 1978-79 season. Deciduous Fruit Grower 30:8-22.

Blanke, M.M. and D.H. Lenz. 1989. Fruit photosynthesis. Plant Cell Environ. 12:31-46.

Burke, J.J. and K.A. Orzech. 1988. The heat-shock response in higher plants: a biochemical model. Plant Cell Environ. 11:441-444.

Chen, K., G. Hu, and F. Lenz. 1998. Apple yield and quality as affected by training and shading. Acta Hort. 466:53-58.

Demmig-Adams, B., W.W. Adams, III, B.A. Logan, and A.S. Verhoeven. 1995. Xanthophyll cycledependent energy dissipation and flexible photosystem II efficiency in plants acclimated to light stress. Austral. J. Plant Physiol. 22:249-260.
Funke, K, M. Blanke, and Klein-Altendorf. 2003. Can reflective ground cover compensate for light losses under hail nets? Erwerbsobstbau 45:137-144.

Glenn, D.M., G.J. Puterka, S.R. Drake, T.R. Unruh, L.A. Knight, P. Baherle, E. Prado, and T.A. Baugher. 2001. Particle film application influences apple leaf physiology, fruit yield and fruit quality. J. Amer. Soc. Hort. Sci. 126:175-81.

Glenn, D.M., E. Prado, A Erez, J. McFerson, and G.J.Puterka.2002.Areflective processed-kaolin particle film affects fruit temperature, radiation reflection and sunburn in apple. J. Amer. Soc. Hort. Sci. 127:188-193.

Guerrero, V.M., J.A. Orozco,A. Romo, A.A. Gardea, F.J. Molina, B. Sastré, and J.J. Martinez. 2002. The effect of hail nets and ethephon on color development of 'Redchief Delicious' apple fruit in the highlands of Chihuahua, Mexico. J. Amer. Pomol. Soc. 56:132-135.

Iglesias, I., J. Graell, G. Echeverría, and M. Vendrell. 2000. Orchard cooling with overtree sprinkler irrigation to improve fruit color of 'Delicious' apples. HortScience 35:1207-1208.

Iglesias, I., J. Salvia, L. Torguet, and C. Cabus. 2002. Orchard cooling with overtree microsprinkler irrigation to improve fruit color and quality of 'Topred Delicious' apples. Sci. Hort. 93:39-51.

Jones, H.G. 1981. Carbon dioxide exchange of developing apple (Malus pumila Mill.) fruits. J. Expt. Bot. 32:1203-1210.

Kerr, J.B. and C.T. McElroy. 1993. Evidence for large upward trends of UV-B radiation linked to ozon depletion. Science 262:1032-1034.

Kotzé, W.A.G., J.A. Carreira, O. Beukes, and A.U. Redelinghuys. 1988. Effect of evaporative cooling on the growth, yield and fruit quality of apples. Deciduous Fruit Grower 38:20-24.

Lambers, H., F.S. Chapin, and T.L. Pons. 1998. Plant physiological ecology. Springer-Verlag, New York.

Le Grange, M, S.J.E. Wand, and K.I. Theron. 2004. Effect of kaolin applications on apple fruit quality and gas exchange of apple leaves. Acta Hort. 636:545-550.

Lipton, W.J. 1977. Ultraviolet radiation as a factor in sunburn and vein tract browning of cantaloupes. J. Amer. Soc. Hort. Sci. 102:32-36.

Ma, F. and L. Cheng. 2003. The sun-exposed peel of apple fruit has higher xanthophyll cycle-dependent thermal dissipation and antioxidants of the ascorbate-glutathione pathway than the shaded peel. Plant Sci. 165:819-827.

Mackerness, S.A.H. and B. Thomas. 1999. Effects of UV-B radiation on plants: gene expression and signal transduction pathways, p. 17-24. In: M.F. Smallwood, C.M. Calvert, and D.J. Bowles (eds.). Plant responses to environmental stresses. Bios Scientific Publ., Oxford.
Melgarejo, P., J.J. Martínez, F. Hernández, R. Martínez-Font, P. Barrows, and A. Erez. 2004. Kaolin treatment to reduce pomegranate sunburn. Scientia Hort. 100:349-353.

Merzlyak, M.N. and A.E. Solovchenko. 2002. Patterns of pigment changes in apple fruits during adaptation to high sunlight and sunscald development. Plant Biochem. and Physiol. 40:679-684.

Müller, P., X.P. Li, and K.K. Niyogi. 2001. Nonphotochemical quenching. Aresponse to excess light energy. Plant Physiol. 125:1558-1566.

Palmer, J.W., J.P. Privé, and D.S. Tustin. 2003. Temperature, p. 217-236. In: D.C. Ferree and I.J. Warrington (eds.). Apples: Botany, production and uses. CABI Publ., Oxon, U.K.

Parchomchuk, P. and M. Meheriuk. 1996. Orchard cooling with pulsed overtree irrigation to prevent sunburn and improve fruit quality of 'Jonagold' apples. HortScience 31:802-804.

Ritenour, M.A., S. Kochhar, L.E. Schrader, T.P. Hsu, and M.S.B. Ku. 2001. Characterization of heat shock protein expression in apple peel under field and laboratory conditions. J. Amer. Soc. Hort. Sci. 126:564-570.

Schrader, L., J. Zhang, and J. Sun. 2003. Environmental stresses that cause sunburn of apple. Acta Hort. 618:397-405.

Schupp, J.R., E. Fallahi, and I.J. Chun. 2002. Effect of particle film on fruit sunburn, maturity and quality of 'Fuji' and 'Honeycrisp' apples. HortTechnology 12:87-90.

Solovchenko, A.E. and M. Schmitz-Eiberger. 2003. Significance of skin flavonoids for UV-B protection in apple fruits. J. Expt. Bot. 54:1977-1984.

Stampar, F., M. Hudina, V. Usenik, K. Sturm, and P. Zadravec. 2001. Influence of black and white nets on photosynthesis, yield and fruit quality of apple (Malus domestica Borkh.). Acta Hort. 557:357-362.

Unrath, C.R. 1972. The quality of 'Red Delicious' apples as affected by overtree sprinkler irrigation. J. Amer. Soc. Hort. Sci. 97:55-58.

Unrath, C.R. and R.E. Sneed. 1974. Evaporative cooling of 'Delicious' apples-The economic feasibility of reducing environmental heat stress. J. Amer. Soc. Hort. Sci. 99:372-375.

Wand, S.J.E., W.J. Steyn, M.J. Mdluli, S.J.S. Marais, and G. Jacobs. 2002. Overtree evaporative cooling for fruit quality enhancement. SA Fruit J. (Aug.-Sept.):18-21.

Widmer, A. 2001. Light intensity and fruit quality under hail protection nets. Acta Hort. 557:421-426.

Wünsche, J,N., T. McGhie, J. Bowen, I., Ferguson, and A. Woolf. 2004. Sunburn on applesCauses and control mechanisms. Acta Hort. 636:631-636. 